\title{
ERRATA
}

\section{Total body phylloquinone and its turnover in human subjects at two levels of vitamin $K$ intake}

\author{
By R. E. Olson, J. Chao, D. Graham, M. W. Bates and J. H. Lewis
}

Volume 87 (2002), Number 6

Page 548, Results, first paragraph, lines 26 to 29

For: $\quad \mu \mathrm{g} / \mathrm{l}$

Read: $\mathrm{mg} / \mathrm{dl}$

\section{Plasma phylloquinone (vitamin $K_{1}$ ) concentration and its relationship to intake in a national sample of British elderly people}

By C. W. Thane, C. J. Bates, M. J. Shearer, N. Unadkat, D. J. Harrington, A. A. Paul, A. Prentice and C. Bolton-Smith

Volume 87 (2002), Number 6

Page 615, Abstract, line 7 (twice)

For: $\quad 95 \% \mathrm{CI}$

Read: inner $95 \%$ range

For: $\quad 95 \%$ CI

Page 617, Results, first paragraph, lines 8 and 19

Read: inner $95 \%$ range 